\title{
Inoculation with Aspergillus aculeatus Alters the Performance of Perennial Ryegrass under Phosphorus Deficiency
}

\author{
Xiaoning Li \\ Coastal Salinity Tolerant Grass Engineering and Technology Research Center, Ludong University, \\ Yantai, Shandong, P.R. China
}

\begin{abstract}
Xiaoyan Sun
Key Laboratory of Horticultural Plant Genetics and Improvement of Jiangxi, Institute of Biology and Resources, Jiangxi Academy of Sciences, Nanchang 330096, P.R. China
Guangyang Wang, Erick Amombo, Xiuwen Zhou, Zhaohong Du, and Yinkun Zhang
Coastal Salinity Tolerant Grass Engineering and Technology Research Center, Ludong University, Yantai, Shandong, P.R. China

Yan Xie ${ }^{1}$

Key Laboratory of Plant Germplasm Enhancement and Specialty Agriculture, Wuhan Botanical Garden, Chinese Academy of Sciences, Wuhan City, P.R. China

Jinmin Fu' ${ }^{1}$

Coastal Salinity Tolerant Grass Engineering and Technology Research Center, Ludong University, Yantai, Shandong, P.R. China
\end{abstract}

\begin{abstract}
AdDitional InDEX woRDs. growth rate, organic acid, P-solubilizing effect, photosynthetic capacity, turf quality
Abstract. Phosphorus (P) is an essential nutrient element that is necessary for plant growth and development. However, most of the $P$ exists in insoluble form. Aspergillus aculeatus has been reported to be able to solubilize insoluble forms of $P$. Here, to investigate the P-solubilizing effect of $A$. aculeatus on the performance of perennial ryegrass (Lolium perenne) under P-deficiency stress, we created four treatment groups: control [i.e., no $\mathrm{Ca}_{3}\left(\mathrm{PO}_{4}\right)_{2}$ or A. aculeatus], A. aculeatus only (F), $\mathrm{Ca}_{3}\left(\mathrm{PO}_{4}\right)_{2}$ and $\mathrm{Ca}_{3}\left(\mathrm{PO}_{4}\right)_{2}+$ A. aculeatus $\left[\mathrm{Ca}_{3}\left(\mathrm{PO}_{4}\right)_{2}+\mathrm{F}\right]$ treatment, and $\mathrm{Ca} 3$ $\left(\mathrm{PO}_{4}\right)_{2}$ at concentrations of 0 and $3 \mathrm{~g}$ per pot $(0.5 \mathrm{~kg}$ substrate per pot). In our results, the liquid medium inoculated with $A$. aculeatus exhibited enhanced soluble $P$ and organic acid content (tartaric acid, citric acid, and aminoacetic acid) accompanied with lower $\mathrm{pH}$, compared with the noninoculated regimen. Furthermore, $A$. aculeatus also played a primary role in increasing the soluble $P$ content of substrate (1 sawdust: 3 sand), the growth rate, turf quality, and photosynthetic capacity of the plant exposed to $\mathrm{Ca}_{3}\left(\mathrm{PO}_{4}\right)_{2}+\mathrm{F}$ treatment, compared with other groups. Finally, in perennial ryegrass leaves, there was a dramatic increase in the valine, serine, tyrosine, and proline contents, and a remarkable decline in the glutamic acid, succinic acid, citric acid, and fumaric acid contents in the $\mathrm{Ca}_{3}\left(\mathrm{PO}_{4}\right)_{2}+\mathbf{F}$ regimen, compared with other groups. Overall, our results suggested that $A$. aculeatus may play a crucial role in the process of solubilizing $\mathrm{Ca}_{3}\left(\mathrm{PO}_{4}\right)_{2}$ and modulating perennial ryegrass growth under $\mathrm{P}$-deficiency stress.
\end{abstract}

Phosphorus is one of the major macronutrients that are essential for plant performance, whose deficiency constrains plant growth and crop productivity (Taktek et al., 2015). Naturally, P exists in organic and inorganic P forms. However, plants absorb only inorganic $\mathrm{P}$, which due to its existence in an insoluble form has a limited abundance in the soil (Dobbelaere et al., 2003; Richardson, 2001). Therefore, P deficiency in the soil is a critical problem for plant growth and agricultural yield (Taktek et al., 2015).

To cope with and overcome such problems, the application of chemical phosphate fertilizers to P-deficient soils is an

Received for publication 29 Oct. 2018. Accepted for publication 27 Feb. 2019. We thank the National Natural Science Foundation of China (grant no. 31772662 and 31772349), Innovation Project of Shandong Forestry Science and Technology (no. LYCX03-2018-13), and the National Key R\&D Program of China (2017YFC0505902; 2016YFC050040501).

${ }^{1}$ Corresponding authors. E-mail: turfen@qq.com or xieyan@wbgcas.cn. inevitable strategy to mitigate $\mathrm{P}$ deficiency (Richardson, 2001). Unfortunately, after application, a large proportion of these $\mathrm{P}$ fertilizers are easily and rapidly converted to insoluble $\mathrm{P}$ because of complex reactions with other cations such as $\mathrm{Fe}^{2+} / \mathrm{Fe}^{3+}, \mathrm{Al}^{3+}$, and $\mathrm{Ca}^{2+}$ in acidic and alkaline soils (Chacon et al., 2006; Khan et al., 2007; Richardson, 2001). Hence, only a fraction of the $\mathrm{P}$ fertilizers introduced into the soil can be absorbed and used by plants (Liu et al., 2014).

To comprehensively address the detrimental effects of $\mathrm{P}$ deficiency on plant growth, some viable and extensive investigations have reported that soil microbes can solubilize insoluble phosphates into a soluble form by secreting phosphatases and organic acids, and thereby enhancing the availability of $\mathrm{P}$ to plants (Richardson et al., 2009; Zhu, 2002). For example, Bacillus and Pseudomonas bacteria, as well as strains of Penicillium and Fusarium fungi, are common P solubilizers (Whitelaw, 2000). In previous research, it was reported that phosphate-solubilizing bacteria mobilize $\mathrm{P}$ from the soil that 
contained organic and inorganic P; thereby, it could be considered as suitable biofertilizers to promote nutrition absorption by plants (Calvo et al., 2014). Furthermore, phosphatesolubilizing bacteria have been reported to play a pivotal role in the solubilization and mobilization of $P$, which enhanced soil fertility (Dobbelaere et al., 2003). Also, it was reported that naturally most terrestrial plants acquired phosphorus sources from the soil due to symbiotic mycorrhizal fungi (Smith and Read, 1997). Furthermore, the application of arbuscular mycorrhizal fungi accelerated plant growth and doubled the absorption of $\mathrm{P}$ under low or medium levels of $\mathrm{P}$ in soil (Weber et al., 1992). Therefore, according to the preceding observations, it was concluded that part of chemical fertilizers can be replaced by biofertilizers that have a better potential to counter P-deficient stress (Velázquez et al., 2010).

In this study, A. aculeatus was isolated from the rhizosphere of bermudagrass (Cynodon dactylon) by Xie et al. (2014a). It was confirmed that the fungus could colonize plant roots and secrete Indole-3-acetic acid, siderophores, and ACC deaminase, thereby alleviating the damage induced by adverse conditions to plants and promoting plant growth and yield (Li et al., 2017; Xie et al., 2017). In addition, $A$. aculeatus can be easily grown in axenic cultures allowing for further vast propagation due to the lack of specificity. Furthermore, an earlier study demonstrated that A. aculeatus had the ability to solubilize natural forms of P (Narsian and Patel, 2000) and solubilize soluble potassium (K) (X.N. Li, unpublished data), which promoted the absorption of $\mathrm{P}$ and $\mathrm{K}$ nutrient elements by plants. Furthermore, A. aculeatus can alleviate the damage caused by stress, such as salt stress (Li et al., 2017; Xie et al., 2017), cadmium stress (Xie et al., 2014a, 2018), high temperature stress (X.N. Li, unpublished data), and drought stress (X.N. Li, unpublished data). However, the role of $A$. aculeatus in improving the performance of perennial ryegrass exposed to $\mathrm{P}$ deficiency is still unexplored. Therefore, A. aculeatus might be considered to be a kind of a biofertilizer when perennial ryegrass is exposed to P-deficiency stress. Perennial ryegrass, with high nutritive values and persistence, is applied extensively as an important forage grass species (Wilkins, 1991). In addition, it is a cool-season turfgrass that is widely used in golf courses, parks, and other places because of its fast establishment, and superior tillering and regeneration ability (Altpeter, 2006; Xiong et al., 2007).

Therefore, the aim of the present study was to explore the mechanism of $A$. aculeatus solubilizing insoluble $\mathrm{P}$ and its subsequent growth-promoting effect on plants grown in $\mathrm{P}$ impoverished soil. Subsequently, we conducted two experiments to evaluate the fungal functions: 1) the P-solubilizing capacity of $A$. aculeatus in a liquid medium, and 2) the effect of $A$. aculeatus on the growth of perennial ryegrass under $\mathrm{P}$ deficiency. To perform the two experiments, we measured some crucial indicators, such as $\mathrm{pH}$, soluble $\mathrm{P}$ and organic acid of the medium, soluble $\mathrm{P}$ of substrate soil, and plant growth indicators.

\section{Materials and Methods}

Expt. 1: The phosphate-solubilizing capacity of $A$. aculeatus in a liquid medium

Fungal Cultures. The fungi $A$. aculeatus, belonging to the genus Aspergillus used in this experiment, were screened and identified by Xie et al. (2014a), which was isolated from the rhizosphere of bermudagrass in Hunan province, central China. Initially, the fungi were removed from a freezer at $-80^{\circ} \mathrm{C}$ and activated in the National Botanical Research Institute's phosphate growth agar (NBRIP) medium including of $0.5 \mathrm{~g}$ $\left(\mathrm{NH}_{4}\right)_{2} \mathrm{SO}_{4}, 0.3 \mathrm{~g} \mathrm{KCl}, 0.3 \mathrm{~g} \mathrm{NaCl}, 0.3 \mathrm{~g} \mathrm{MgSO}_{4} \cdot 7 \mathrm{H}_{2} \mathrm{O}, 0.03 \mathrm{~g}$ $\mathrm{FeSO}_{4} \cdot 7 \mathrm{H}_{2} \mathrm{O}, 0.03 \mathrm{~g} \mathrm{MnSO}_{4} \cdot \mathrm{H}_{2} \mathrm{O}, 10 \mathrm{~g}$ glucose, $20 \mathrm{~g}$ agar, diluted with distilled water to $1 \mathrm{~L}$, which was kept in a growth chamber at $30{ }^{\circ} \mathrm{C}$ for $7 \mathrm{~d}$ (30 May to 6 June 2017).

$\mathrm{CA}_{3}\left(\mathrm{PO}_{4}\right)_{2}$ TREatment and EXPERIMENTAL Design. For $\mathrm{Ca}_{3}\left(\mathrm{PO}_{4}\right)_{2}$ treatment, 0,3 , and $5 \mathrm{~g} \cdot \mathrm{L}^{-1} \mathrm{Ca}_{3}\left(\mathrm{PO}_{4}\right)_{2}$ were added to the liquid NBRIP medium containing $0.5 \mathrm{~g}\left(\mathrm{NH}_{4}\right)_{2} \mathrm{SO}_{4}, 0.3 \mathrm{~g}$ $\mathrm{KCl}, 0.3 \mathrm{~g} \mathrm{NaCl}, 0.3 \mathrm{~g} \mathrm{MgSO}_{4} \cdot 7 \mathrm{H}_{2} \mathrm{O}, 0.03 \mathrm{~g} \mathrm{FeSO}_{4} \cdot 7 \mathrm{H}_{2} \mathrm{O}, 0.03 \mathrm{~g}$ $\mathrm{MnSO}_{4} \cdot \mathrm{H}_{2} \mathrm{O}, 10 \mathrm{~g}$ glucose, with $1 \mathrm{~L}$ of distilled water. Subsequently, the liquid NBRIP medium was poured into a $250-\mathrm{mL}$ erlenmeyer flask filled to $150 \mathrm{~mL}$ and sterilized in an autoclave for $20 \mathrm{~min}$ at $121{ }^{\circ} \mathrm{C}$. In addition, the mycelium was gently scraped into the sterile water from the surface of the NBRIP agar medium on 8 June 2017, and then the fungus suspension (optical density at $600 \mathrm{~nm}=0.65$ ) was prepared. The liquid medium was divided into two groups: one was inoculated with $6 \mathrm{~mL}$ fungus suspension per $150 \mathrm{~mL}$ liquid medium and the other was left uninoculated. Finally, all flasks were placed on a shaker at 200 $g_{\mathrm{n}}$ at $30^{\circ} \mathrm{C}$, and the supernatant was collected to measure the $\mathrm{pH}$; soluble $\mathrm{P}$ content on days 0,3 , and $6(8,11$, and 14 June 2017 , respectively); and organic acid content in the medium on days 3 and 6.

\section{Measurements}

Determination of PH and soluble $\mathbf{P}$ of medium. After inoculation for 0,3 , and $6 \mathrm{~d}$, the medium was centrifuged at $10,000 g_{\mathrm{n}}$ for $5 \mathrm{~min}$, and then the supernatant was collected. The $\mathrm{pH}$ of the medium was recorded using a $\mathrm{pH}$ meter equipped with a glass electrode. The content of soluble phosphate was determined by an automatic chemical analyzer (EasyChem Plus; Systea, Anagni, Italy) based on the molybdate blue method (Murphy and Riley, 1962).

OrganIC ACID OF MEDIUM. For the organic acids content analysis, a high-performance liquid chromatography (HPLC) system (Accela 1250; Thermo Fisher Scientific, Waltham, MA) was used on 15 June 2017 (Shui and Leong, 2002). The medium was centrifuged at $10,000 \mathrm{~g}_{\mathrm{n}}$ for $5 \mathrm{~min}$ when inoculated for 0,3 , and $6 \mathrm{~d}$, and then the supernatant was collected. The supernatant was filtered through a $0.22-\mu \mathrm{m}$ membrane filter and then $0.5 \mathrm{~mL}$ of filtrates was injected into 2-mL HPLC vials for HPLC determination. The separation was carried out on a $250 \times$ 4.6-mm, 5- $\mu \mathrm{m}$ column (Diamonsil C18; Dikma Technologies, Foothill Ranch, CA). Detection was operated at 214-nm wavelength with $0.1 \mathrm{mmol} \cdot \mathrm{L}^{-1} \mathrm{KH}_{2} \mathrm{PO}_{4}(\mathrm{pH}=2.6)$ as mobile phase passed through a $0.45-\mu \mathrm{m}$ membrane filter. The $\mathrm{C} 18$ column was operated with $0.5 \mathrm{~mL} \cdot \mathrm{min}^{-1}$ flow rate at $30{ }^{\circ} \mathrm{C}$ of column temperature and the sample injection volume was $20 \mu \mathrm{L}$. Every analysis was replicated three times.

\section{Expt. 2: The effect of $A$. aculeatus on the growth of perennial ryegrass under $P$ deficiency}

Preparation of the growth substances. The growth substrate used in this study consisted of a mixture of sawdust (P-free with 3-6 mm particles) and sand [1 sawdust: 3 sand $(\mathrm{v} / \mathrm{v}), \mathrm{pH}=6.5]$, which was prepared on 20 June 2017. All the sand mixes were sterilized in an autoclave for $1 \mathrm{~h}$ at $127^{\circ} \mathrm{C}$ and then were dispensed into plastic pots $(9.5 \mathrm{~cm}$ diameter and $18 \mathrm{~cm}$ deep; $0.5 \mathrm{~kg}$ mixture per pot). All the plastic pots were 
drilled at the bottom to enhance the substrate ventilation and drainage and were sterilized by ultraviolet (Ultraviolet Ray; Philips, Amsterdam, The Netherlands) for 1 h. Subsequently, the growth substances were divided into two groups, namely $\mathrm{Ca}_{3}\left(\mathrm{PO}_{4}\right)_{2}$ and $\mathrm{Ca}_{3}\left(\mathrm{PO}_{4}\right)_{2}+$ A. aculeatus $\left[\mathrm{Ca}_{3}\left(\mathrm{PO}_{4}\right)_{2}+\mathrm{F}\right]$.

The $A$. aculeatus isolate used in this study was activated with NBRIP agar medium for $7 \mathrm{~d}$ and then was inoculated in $250-\mathrm{mL}$ erlenmeyer flasks filled with $150 \mathrm{~mL}$ NBRIP liquid medium. All flasks were kept on the shaker at $200 g_{n}$ for $48 \mathrm{~h}$ at $30^{\circ} \mathrm{C}$ on 21 June 2017. For $\mathrm{Ca}_{3}\left(\mathrm{PO}_{4}\right)_{2}+\mathrm{F}$ group, the fungi inoculated in liquid NBRIP medium was filtered with a wire gauze and washed three times with sterile water, and then was resuspended. Subsequently, $10 \mathrm{~mL}$ of spore suspension $\left(\approx 10^{6}\right.$ colony-forming units $/ \mathrm{mL}$ ) were inoculated into the pot and thoroughly mixed into the substrate on 23 June 2017; and then substrates were cultivated in a growth chamber at $30^{\circ} \mathrm{C}$ for $48 \mathrm{~h}$ before the seeds were sowed.

Plant materials and growth Conditions. The perennial ryegrass 'Lark' seeds ( $0.5 \mathrm{~g}$ per pot) were surface-sterilized with $70 \%$ ethanol $(5 \mathrm{~min})$ and then with $0.1 \% \mathrm{HgCl}_{2}(5 \mathrm{~min})$, and then washed five times using sterile water. Subsequently, the seeds were sown evenly in plastic pots $(9.5 \mathrm{~cm}$ diameter, 18 $\mathrm{cm}$ deep) filled with the pre-prepared mixture of sand and sawdust (as described previously) and covered by a $0.5-\mathrm{cm}$ layer of sand on 26 June 2017. After germination, the materials were watered daily and fertilized twice weekly with halfstrength Hoagland nutrient solution (in the absence of phosphorus source) including $\mathrm{KNO}_{3}(2.5 \mathrm{~mm}), \mathrm{Ca}\left(\mathrm{NO}_{3}\right)_{2} \cdot 4 \mathrm{H}_{2} \mathrm{O}$ $(2.5 \mathrm{~mm}), \mathrm{MgSO}_{4} \cdot 7 \mathrm{H}_{2} \mathrm{O}(1 \mathrm{~mm}), \mathrm{H}_{3} \mathrm{BO}_{3}\left(1.43 \mathrm{mg} \cdot \mathrm{L}^{-1}\right)$, $\mathrm{ZnSO}_{4} \cdot 7 \mathrm{H}_{2} \mathrm{O}\left(0.11 \mathrm{mg} \cdot \mathrm{L}^{-1}\right), \mathrm{CuSO}_{4} \cdot 5 \mathrm{H}_{2} \mathrm{O}\left(0.04 \mathrm{mg} \cdot \mathrm{L}^{-1}\right)$, $\mathrm{MnCl}_{2} \cdot 4 \mathrm{H}_{2} \mathrm{O}\left(0.91 \mathrm{mg} \cdot \mathrm{L}^{-1}\right), \mathrm{H}_{2} \mathrm{MoO}_{4}\left(0.05 \mathrm{mg} \cdot \mathrm{L}^{-1}\right)$, FeEDTA $(0.04 \mathrm{~mm})$. All grasses were maintained in a greenhouse with natural illumination for 7 weeks to allow for establishing the leaves and roots of the plant with a daily temperature of $21 \pm$ $3 / 18 \pm 3{ }^{\circ} \mathrm{C}$ (day/night) and 14-h photoperiod (from 26 June to 14 Aug. 2017).

EXPERIMENTAL DESIGN AND SAMPLING. All materials were divided into four groups: control $\left\{\mathrm{CK}\left[\right.\right.$ no $\mathrm{Ca}_{3}\left(\mathrm{PO}_{4}\right)_{2}$ or $A$. aculeatus in medium] $\}, A$. aculeatus only $(\mathrm{F}), \mathrm{Ca}_{3}\left(\mathrm{PO}_{4}\right)_{2}$, and $\mathrm{Ca}_{3}\left(\mathrm{PO}_{4}\right)_{2}+$ A. aculeatus $\left[\mathrm{Ca}_{3}\left(\mathrm{PO}_{4}\right)_{2}+\mathrm{F}\right]$ treatment, and $\mathrm{Ca}_{3}\left(\mathrm{PO}_{4}\right)_{2}$ concentrations were 0 and $3 \mathrm{~g}$ per pot $(0.5 \mathrm{~kg}$ substrate per pot). After 7 weeks of the establishment, the shoot lengths were measured to assess the relative growth rate and subsequently the leaf samples were harvested for accessing other parameters on 14 Aug. 2017. During harvest, the medium was collected for measuring the $\mathrm{PH}$ and soluble $\mathrm{P}$ of medium. The $\mathrm{Ca}_{3}\left(\mathrm{PO}_{4}\right)_{2}$ treatment and concentration were randomized in a complete block design with five replicates.

\section{Measurements}

Determination of soluble $P$ in the growth substrate. The $2.5 \mathrm{~g}$ of crushed and screened substrate samples were placed into a $250-\mathrm{mL}$ erlenmeyer flask, in which $50 \mathrm{~mL}$ of $0.5 \mathrm{M} \mathrm{NaHCO}_{3}$ extractant and $5 \mathrm{~g}$ non-P active carbon were added; and then the mixture was shaken on a rotary shaker for $30 \mathrm{~min}$ at $250 \mathrm{~g}_{\mathrm{n}}$. Subsequently, $6 \mathrm{~mL}$ of $14 \% \mathrm{H}_{2} \mathrm{SO}_{4}$ was added to flasks to escape the $\mathrm{CO}_{2}$ and then the mixture was filtered through a qualitative filter paper for further measurement. The content of soluble phosphate was measured with an automatic chemical analyzer (EasyChem Plus) based on molybdate blue method (Murphy and Riley, 1962) on 20 Aug. 2017.
Determination OF PH IN THE GROWTH SUbSTRATE. Medium $\mathrm{pH}$ was evaluated by immersing a glass electrode with medium-water suspensions that were whisked with a glass rod for $2 \mathrm{~min}$ and kept for $30 \mathrm{~min}$ at room temperature on 21 Aug. 2017.

RELATIVE GROWTH RATE. The relative growth rate of shoots (RGR) was estimated by measuring the turf vertical average height above the growth substances at the end of the experiment on 14 Aug. 2017. The final height was recorded as $H_{t}$ at the end of the experiment. The duration of the experiment was recorded as $\Delta t$. The RGR of the materials was calculated according to the equation: $\mathrm{RGR}=\mathrm{H}_{\mathrm{t}} / \Delta t$.

\section{Turf quality estimation}

Turf quality was evaluated visually based on a scale of 0 to 9 on a weekly basis according to turfgrass color on 14 Aug. 2017, where $0=$ yellow, withered, thin, and dead; $6=$ minimum acceptable level based on density, turf color, and uniformity; and 9 = green, dense, and uniform (Turgeon, 1991).

\section{Quantification of chlorophyll $\boldsymbol{a}$ fluorescence transient}

Chlorophyll $a$ fluorescence transient (OJIP transient) can be used to measure the photosynthetic processes efficiency and kinetics that are involved in photosystem II (PSII) (Chen et al., 2013). [About OJIP curve: $F_{\mathrm{O}}$ : minimal reliable recorded fluorescence, at $20 \mu \mathrm{s}$ with the pulse-amplitude modulation (PAM) fluorometer; $\mathrm{F}_{\mathrm{J}}$ : fluorescence intensity at the J-step $(2 \mathrm{~ms})$ of OJIP; $\mathrm{F}_{\mathrm{I}}$ : Fluorescence intensity at the I-step $(30 \mathrm{~ms})$ of OJIP; $\mathrm{F}_{\mathrm{P}}$ : maximal recorded fluorescence intensity, at the peak P of OJIP.] OJIP transient was determined on 14 Aug. 2017 according to the method described by Chen et al. (2013) using a pulse-amplitude modulation fluorometer (PAM 2500; Heinz Walz, Efeltrich, Germany) with a high time resolution of $10 \mu \mathrm{s}$. At the end of the experiment, the fourth fully expanded leaves were placed in a dark room for 30 min dark adaptation to close all reaction centers of PS II and obtain the maximal fluorescence yield. After dark adaptation, the OJIP curves were evaluated with a red light of $3000 \mu \mathrm{mol} \cdot \mathrm{m}^{-2} \cdot \mathrm{s}^{-1}$ to acquire the maximum fluorescence intensity $\left(\mathrm{F}_{\mathrm{M}}\right)$. The chlorophyll $a$ fluorescence emission was induced by the strong light pulses and then was determined and digitized between $10 \mu \mathrm{s}$ and 320 $\mathrm{ms}$. The OJIP curve was analyzed by the JIP test as described in Table 1.

\section{Metabolite extraction and derivatization}

For the metabolite assay, fully expanded perennial ryegrass leaves $(\approx 0.3 \mathrm{~g})$ were harvested on 25 Aug. 2017 after experimental treatment, and frozen immediately in liquid nitrogen, then stored in the refrigerator at $-80{ }^{\circ} \mathrm{C}$ until further analysis. The metabolite extraction and sample derivatization were extracted according to the protocol as described previously (Xie et al., 2014b). The frozen plant samples were ground into a fine powder in liquid nitrogen with prechilled mortar and pestle, then the powder was transferred into a 2$\mathrm{mL}$ centrifuge tube containing $4.2 \mathrm{~mL}$ of $80 \%(\mathrm{v} / \mathrm{v})$ aqueous methanol. Subsequently, the tubes were shaken for $2 \mathrm{~h}$ at $200 g_{\mathrm{n}}$ at ambient temperature, and then $60 \mu \mathrm{L}$ of ribitol $\left(2 \mathrm{mg} \cdot \mathrm{mL}^{-1}\right)$ was added into the solution as internal standard. After that, the solution was heated in a water bath at $70^{\circ} \mathrm{C}$ for $15 \mathrm{~min}$ and centrifuged for $15 \mathrm{~min}$ at $12,000 \mathrm{~g}_{\mathrm{n}}$, and then the supernatant was transferred into a new $10-\mathrm{mL}$ centrifuge tube 
Table 1. Parameters for analysis of tartaric, malic, citric, and aminoacetic acids in liquid medium via high-performance liquid chromatography on days 3 and 6 after the addition of Aspergillus aculeatus (F).

\begin{tabular}{|c|c|c|c|c|c|}
\hline \multirow[b]{2}{*}{ Time } & \multirow[b]{2}{*}{ Treatment $\left[\mathrm{g} \cdot \mathrm{L}^{-1} \mathrm{Ca}_{3}\left(\mathrm{PO}_{4}\right)_{2}\right]^{\mathrm{z}}$} & Tartaric acid & Malic acid & Citric acid & Aminoacetic acid \\
\hline & & \multicolumn{4}{|c|}{$\left[\right.$ mean \pm SD $\left.\left(\mathrm{mg} \cdot \mathrm{mL}^{-1}\right)\right]$} \\
\hline \multirow[t]{2}{*}{ Day 3} & $0+\mathrm{F}$ & $0.571 \pm 0.02 \mathrm{a}^{\mathrm{y}}$ & $0.226 \pm 0.11 \mathrm{a}$ & $0.025 \pm 0.00 \mathrm{a}$ & $0.037 \pm 0.02 \mathrm{a}$ \\
\hline & $3+F$ & $0.508 \pm 0.02 \mathrm{~b}$ & $0.185 \pm 0.01 \mathrm{a}$ & $0.063 \pm 0.03 \mathrm{a}$ & $0.036 \pm 0.01 \mathrm{a}$ \\
\hline \multirow[t]{3}{*}{ Day 6} & $0+\mathrm{F}$ & $0.770 \pm 0.04 \mathrm{~b}^{*}$ & UD & $0.055 \pm 0.00 \mathrm{~b}^{*}$ & $0.080 \pm 0.01 \mathrm{a}^{*}$ \\
\hline & $3+F$ & $0.768 \pm 0.08 \mathrm{~b}^{*}$ & UD & $0.283 \pm 0.11 \mathrm{ab}^{*}$ & $0.077 \pm 0.03 \mathrm{a}$ \\
\hline & $5+F$ & $1.101 \pm 0.21 \mathrm{a}^{*}$ & UD & $0.466 \pm 0.17 \mathrm{a}$ & $0.114 \pm 0.012 \mathrm{a}^{*}$ \\
\hline
\end{tabular}

${ }^{\mathrm{z}}$ Treatments consisted of 0,3 , and $5 \mathrm{~g} \cdot \mathrm{L}^{-1} \mathrm{Ca}_{3}\left(\mathrm{PO}_{4}\right)_{2}$ added to a liquid medium containing $0.5 \mathrm{~g}\left(\mathrm{NH}_{4}\right)_{2} \mathrm{SO}_{4}, 0.3 \mathrm{~g} \mathrm{KCl}, 0.3 \mathrm{~g} \mathrm{NaCl}, 0.3 \mathrm{~g} \mathrm{MgSO}{ }_{4}$. $7 \mathrm{H}_{2} \mathrm{O}, 0.03 \mathrm{~g} \mathrm{FeSO}_{4} \cdot 7 \mathrm{H}_{2} \mathrm{O}, 0.03 \mathrm{~g} \mathrm{MnSO}_{4} \cdot \mathrm{H}_{2} \mathrm{O}$, and $10 \mathrm{~g}$ glucose, in $1 \mathrm{~L}$ distilled water. The liquid medium was divided into two groups: one was inoculated with $6 \mathrm{~mL}$ fungal suspension per $150 \mathrm{~mL}$ liquid medium and the other was left inoculated for subsequent organic acid determination. ${ }^{\mathrm{y}}$ Different letters indicate significant differences under three different $\mathrm{Ca}_{3}\left(\mathrm{PO}_{4}\right)_{2}$ concentration on days 3 or 6 .

${ }^{*}$ Significant differences between days 3 and 6 with the same $\mathrm{Ca}_{3}\left(\mathrm{PO}_{4}\right)_{2}$ concentrations based on Student-Newman-Keuls test combining one-way analysis of variance $(P<0.05)$.

$\mathrm{UD}=$ undeterminable.

containing $4.5 \mathrm{~mL}$ of deionized water and $2.25 \mathrm{~mL}$ of chloroform. The mixture solution was vortexed fully for 15 $\mathrm{s}$ and centrifuged at $10,000 \mathrm{~g}_{\mathrm{n}}$ for $10 \mathrm{~min}$. The supernatant (i.e., polar phase), $0.3 \mathrm{~mL}$, was transferred into 2 -mL HPLC vials and then was dried using a centrifugal concentrator at $900 g_{\mathrm{n}}$ overnight. The dried polar phase was derivatized with $80 \mathrm{~mL}$ of methoxyamine hydrochloride $\left(20 \mathrm{mg} \cdot \mathrm{mL}^{-1}\right)$ dissolved in pyridine at $30^{\circ} \mathrm{C}$ for $2 \mathrm{~h}$ and was trimethylsilylated with $50 \mu \mathrm{L} \mathrm{N}$-methyl-N-trimethylsilyltrifluoroacetamide (MSTFA) for $2 \mathrm{~h}$ at $30^{\circ} \mathrm{C}$. The reagents used in our research were purchased from Sigma-Aldrich (Poole, UK).

\section{Gas chromatography-mass spectrometry (GC-MS) analysis}

The metabolites were measured using a GC-MS (7890A/ 5975C; Agilent Technologies, Palo Alto, CA) analysis based on the protocol of Xie et al. (2014b). For GC-MS, the derivatization samples $(1 \mu \mathrm{L})$ were injected into a $30 \mathrm{~m} \times 0.25 \mathrm{~mm} \times 0.25$ $\mu \mathrm{m}$ capillary column (DB-5MS; Agilent Technologies). The procedure was performed as follows: the inlet temperature was set at $280{ }^{\circ} \mathrm{C}$ and $5 \mathrm{~min}$ solvent delay. Subsequently, the initial GC oven temperature was set at $70^{\circ} \mathrm{C} ; 1$ min after injection, the temperature of the $\mathrm{GC}$ oven was increased to $280{ }^{\circ} \mathrm{C}$ with $5{ }^{\circ} \mathrm{C}$ per min, and then kept at $280{ }^{\circ} \mathrm{C}$ for $10 \mathrm{~min}$. The injection temperature was set at $280^{\circ} \mathrm{C}$, while the ion source temperature was adjusted to $230^{\circ} \mathrm{C}$. Helium was used as the carrier gas with a constant flow rate set at $1 \mathrm{~mL}$ per min. The measurement was recorded at two scans per s with $70 \mathrm{eV}$ of electron impact ionization in a full scan mode ( $\mathrm{m} / \mathrm{z}$ range $30-650)$.

\section{Metabolite data processing and analysis}

The metabolites were processed and analyzed with software (MSD Productivity Chemstation; Agilent) by the retention time coupled with available compound libraries of National Institute of Standards and Technology (NIST 11; NIST, Gaithersburg, MD). Relative quantification of the metabolite was calculated according to the internal standard (ribitol).

\section{Statistical analysis}

Statistical analysis was performed using the program SPSS (version 16.0; IBM Corp., Armonk, NY). Statistical differences $(P<0.05)$ were estimated using the Student-Newman-Keuls test combining one-way analysis of variance.

\section{Results}

\section{The phosphate-solubilizing capacity of $A$. aculeatus in the liquid medium}

The A. aculeatus exhibited strong phosphate-solubilizing characteristics. As shown in Fig. 1A-C, soluble P content was 12.7- or 10.2-fold higher in the $\mathrm{Ca}_{3}\left(\mathrm{PO}_{4}\right)_{2}+\mathrm{F}$ group than in the $\mathrm{Ca}_{3}\left(\mathrm{PO}_{4}\right)_{2}$ group, when the concentration of $\mathrm{Ca}_{3}\left(\mathrm{PO}_{4}\right)_{2}$ was 3 or $5 \mathrm{~g}$ on the $6 \mathrm{~d}$. As expected, in Fig. $2 \mathrm{~A}-\mathrm{C}$, the $\mathrm{pH}$ of the liquid medium was remarkably decreased by $A$. aculeatus when compared with the $\mathrm{Ca}_{3}\left(\mathrm{PO}_{4}\right)_{2}$ group at days 3 and 6 , regardless of $\mathrm{Ca}_{3}\left(\mathrm{PO}_{4}\right)_{2}$ concentration. When the concentration of $\mathrm{Ca}_{3}\left(\mathrm{PO}_{4}\right)_{2}$ was 0,3 , and $5 \mathrm{~g}$, the $\mathrm{pH}$ of the liquid medium decreased by $2.90-, 1.98-$, and 1.65 -fold, respectively, in the $\mathrm{Ca}_{3}\left(\mathrm{PO}_{4}\right)_{2}+\mathrm{F}$ group than in the $\mathrm{Ca}_{3}\left(\mathrm{PO}_{4}\right)_{2}$ group on day 6 .

A decline in the $\mathrm{pH}$ of the liquid medium was accompanied by the production of organic acids by $A$. aculeatus. As observed in Table 1, when $\mathrm{Ca}_{3}\left(\mathrm{PO}_{4}\right)_{2}$ was absent in the liquid medium, the fungus also could produce organic acids (tartaric acid, malic acids, citric acid, and aminoacetic acid). In addition, when the concentration of $\mathrm{Ca}_{3}\left(\mathrm{PO}_{4}\right)_{2}$ was $3 \mathrm{~g}$, the content of tartaric acid, citric acid, and aminoacetic acid in the liquid medium was 1.51-, 4.49-, and 2.14-fold higher on day 6 than day 3 . Simultaneously, when the concentration of $\mathrm{Ca}_{3}\left(\mathrm{PO}_{4}\right)_{2}$ was $5 \mathrm{~g}$, the content of tartaric acid and aminoacetic acid was 2.16- and 1.93-fold higher on day 6 than day 3 .

\section{The phosphate-solubilizing capacity of $A$. aculeatus in the medium}

Plant growth performance. The result is shown in Fig. 3, where $A$. aculeatus dramatically increased plant turf quality and relative growth rate, regardless of $\mathrm{Ca}_{3}\left(\mathrm{PO}_{4}\right)_{2}$ application. In addition, the turf quality was 1.30 -fold higher in the $\mathrm{Ca}_{3}\left(\mathrm{PO}_{4}\right)_{2}+$ $F$ regimen than in the $\mathrm{Ca}_{3}\left(\mathrm{PO}_{4}\right)_{2}$ regimen. Simultaneously, the relative growth rate had a 1.21-fold increase in the $\mathrm{Ca}_{3}\left(\mathrm{PO}_{4}\right)_{2}+\mathrm{F}$ regimen than in the $\mathrm{Ca}_{3}\left(\mathrm{PO}_{4}\right)_{2}$ regimen (Fig. 3).

Soluble $\mathbf{P}$ and PH OF THE MEdium. A. aculeatus could solubilize $\mathrm{Ca}_{3}\left(\mathrm{PO}_{4}\right)_{2}$ into soluble phosphate in the medium. As exhibited in Fig. 4, in the $\mathrm{Ca}_{3}\left(\mathrm{PO}_{4}\right)_{2}+\mathrm{F}$ group, the soluble $\mathrm{P}$ accumulation increased by 1.77-, 2.77-, and 2.87-fold, respectively, compared with the $\mathrm{Ca}_{3}\left(\mathrm{PO}_{4}\right)_{2}$ group, $\mathrm{F}$ group, and CK. Simultaneously, the $\mathrm{pH}$ of medium was 1.23-, 1.23-, and 1.07-fold higher after inoculation of fungi in the $\mathrm{Ca}_{3}\left(\mathrm{PO}_{4}\right)_{2}+$ $\mathrm{F}$ group compared with the control, $\mathrm{F}$, and $\mathrm{Ca}_{3}\left(\mathrm{PO}_{4}\right)_{2}$ groups. 

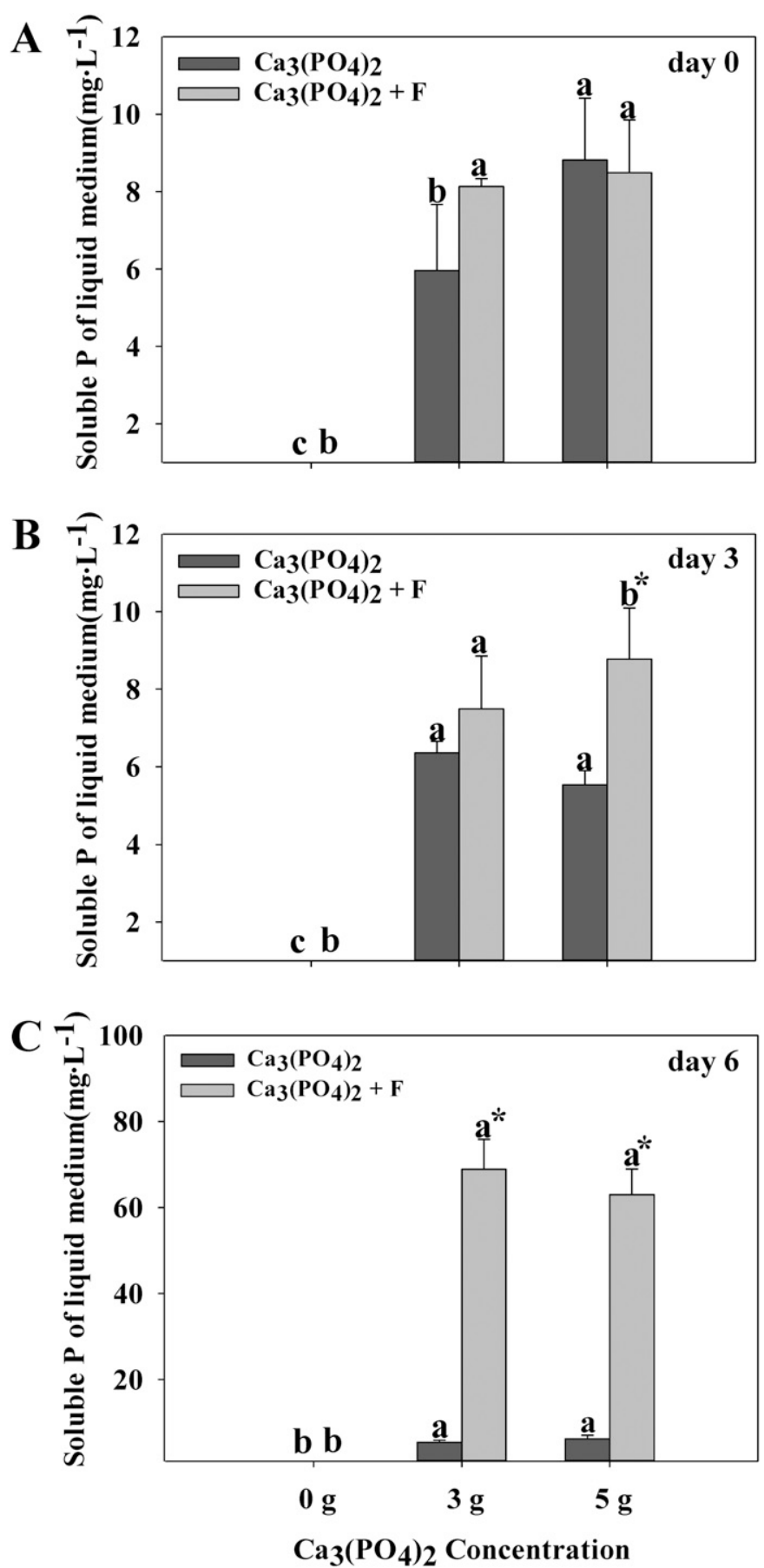

Fig. 1. Bar plots showing the influences of the Aspergillus aculeatus (F) on soluble phosphorus content $(\mathbf{A}-\mathbf{C})$ in a liquid medium. Columns marked with same small letter indicate insignificant differences under only $\mathrm{Ca}_{3}\left(\mathrm{PO}_{4}\right)_{2}$ treatment or $\mathrm{Ca}_{3}\left(\mathrm{PO}_{4}\right)_{2}+\mathrm{F}$ treatment with the different $\mathrm{Ca}_{3}\left(\mathrm{PO}_{4}\right)_{2}$ concentrations $(P<0.05)$. Columns marked with an asterisk indicate significant differences under $\mathrm{Ca}_{3}\left(\mathrm{PO}_{4}\right)_{2}$ treatment or $\mathrm{Ca}_{3}\left(\mathrm{PO}_{4}\right)_{2}+\mathrm{F}$ treatment with the same $\mathrm{Ca}_{3}\left(\mathrm{PO}_{4}\right)_{2}$ concentrations $(P<0.05)$.

Photosynthetic efficiency. A combination of $A$. aculeatus and $\mathrm{Ca}_{3}\left(\mathrm{PO}_{4}\right)_{2}$ treatment notably affected the OJIP fluorescence transient curves of the plant leaves (Fig. 5). According to the observations, the OJIP transient curve in the $\mathrm{Ca}_{3}\left(\mathrm{PO}_{4}\right)_{2}+\mathrm{F}$ group was higher than other groups (Fig. 5 combined with Table 2). To explore the OJIP fluorescence transient curves, the
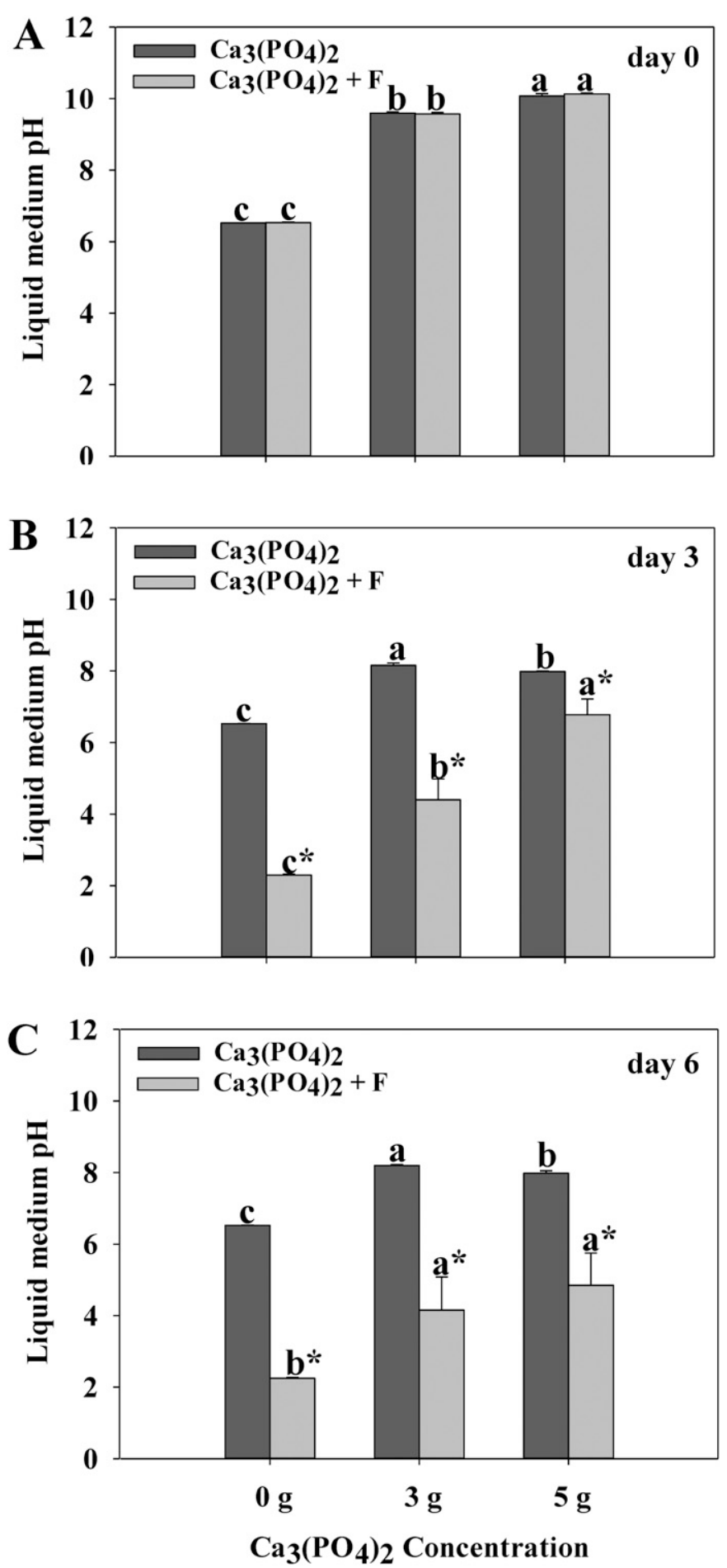

Fig. 2. Bar plots showing the influences of the Aspergillus aculeatus (F) on $\mathrm{pH}$ $(\mathbf{A}-\mathbf{C})$ in a liquid medium. Columns marked with same small letter indicate insignificant differences under only $\mathrm{Ca}_{3}\left(\mathrm{PO}_{4}\right)_{2}$ treatment or $\mathrm{Ca}_{3}\left(\mathrm{PO}_{4}\right)_{2}+\mathrm{F}$ treatment with the different $\mathrm{Ca}_{3}\left(\mathrm{PO}_{4}\right)_{2}$ concentrations $(P<0.05)$. Columns marked with an asterisk indicate significant differences under $\mathrm{Ca}_{3}\left(\mathrm{PO}_{4}\right)_{2}$ treatment or $\mathrm{Ca}_{3}\left(\mathrm{PO}_{4}\right)_{2}+\mathrm{F}$ treatment with the same $\mathrm{Ca}_{3}\left(\mathrm{PO}_{4}\right)_{2}$ concentrations $(P<0.05)$.

JIP test was applied. The basic fluorescence values were extracted from OJIP curves to analyze the structural and functional parameters. As shown in Table 2, basic parameters, including $\mathrm{F}_{\mathrm{J}}, \mathrm{F}_{\mathrm{I}}$, and $\mathrm{F}_{\mathrm{P}}$, displayed an upregulated trend when 

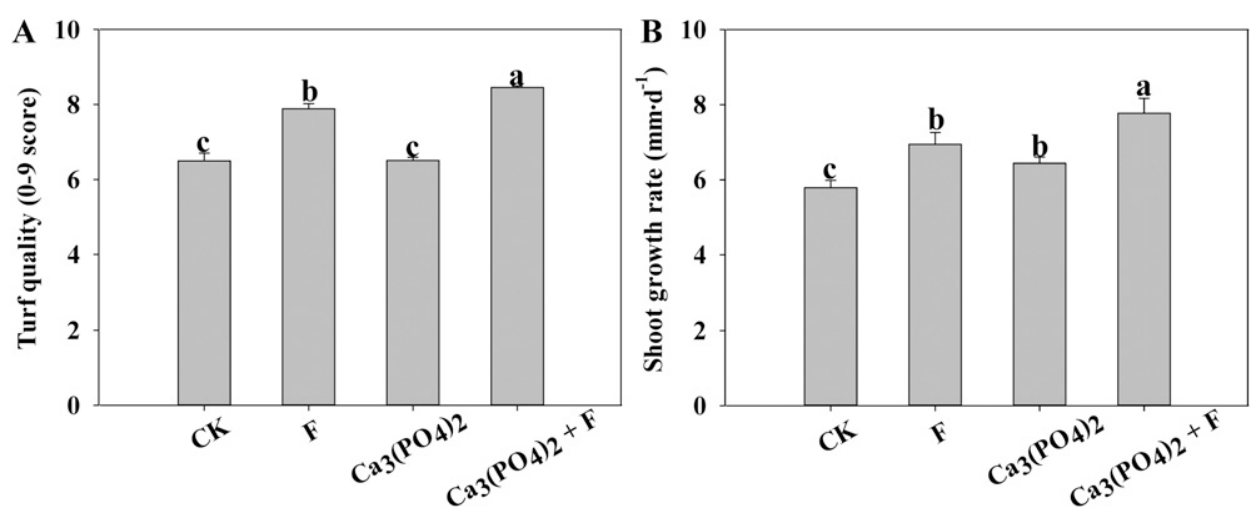

Fig. 3. Bar plots showing the influences of the Aspergillus aculeatus (F) on turf quality (A) and relative growth rate (B) of perennial ryegrass. $\mathrm{CK}$ represents control [i.e., no $\mathrm{Ca}_{3}\left(\mathrm{PO}_{4}\right)_{2}$ and $\mathrm{F}$ in medium]. $\mathrm{Ca}_{3}\left(\mathrm{PO}_{4}\right)_{2}$ concentration was 0 and $3 \mathrm{~g}$ per pot $(0.5 \mathrm{~kg}$ growth substrate). Turf quality was evaluated visually based on a score of 0 to 9 , where 0 =yellow, withered, thin, and dead; $6=$ minimum acceptable level based on density, turf color, and uniformity; and $9=$ green, dense, and uniform. The numbers marked with the same small letter indicate insignificant differences under four different treatments $(P<0.05)$.
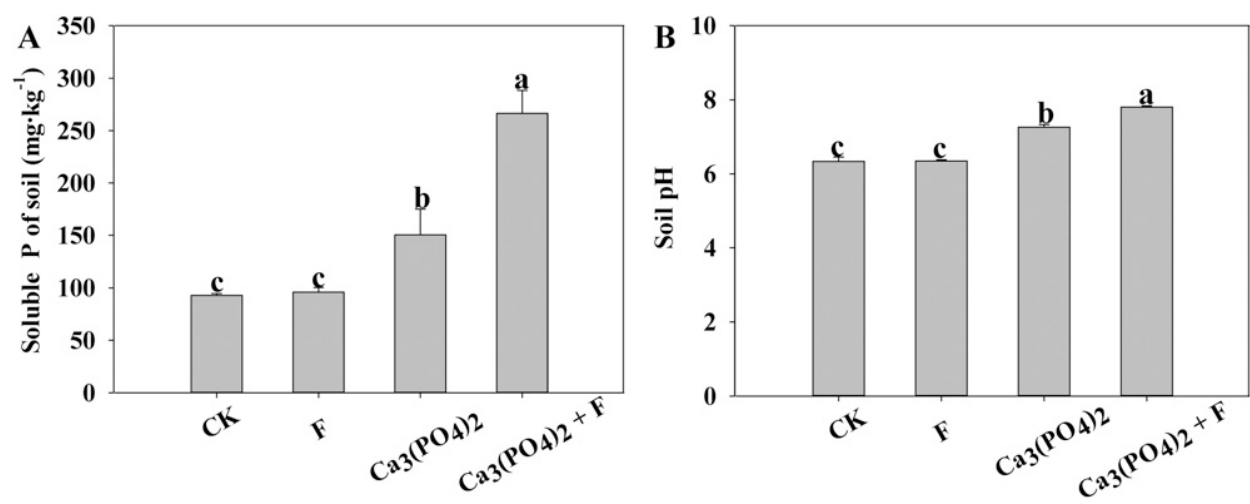

Fig. 4. Bar plots showing the influences of the Aspergillus aculeatus (F) on soluble phosphorus content (A) and $\mathrm{pH}$ (B) in medium. CK represents control [i.e., no $\mathrm{Ca}_{3}\left(\mathrm{PO}_{4}\right)_{2}$ and A. aculeatus in medium]. $\mathrm{Ca}_{3}\left(\mathrm{PO}_{4}\right)_{2}$ concentration was 0 and $3 \mathrm{~g}$ per pot $(0.5 \mathrm{~kg}$ growth substrate). The numbers marked with the same small letter indicate insignificant differences under four different treatments $(P<0.05)$.

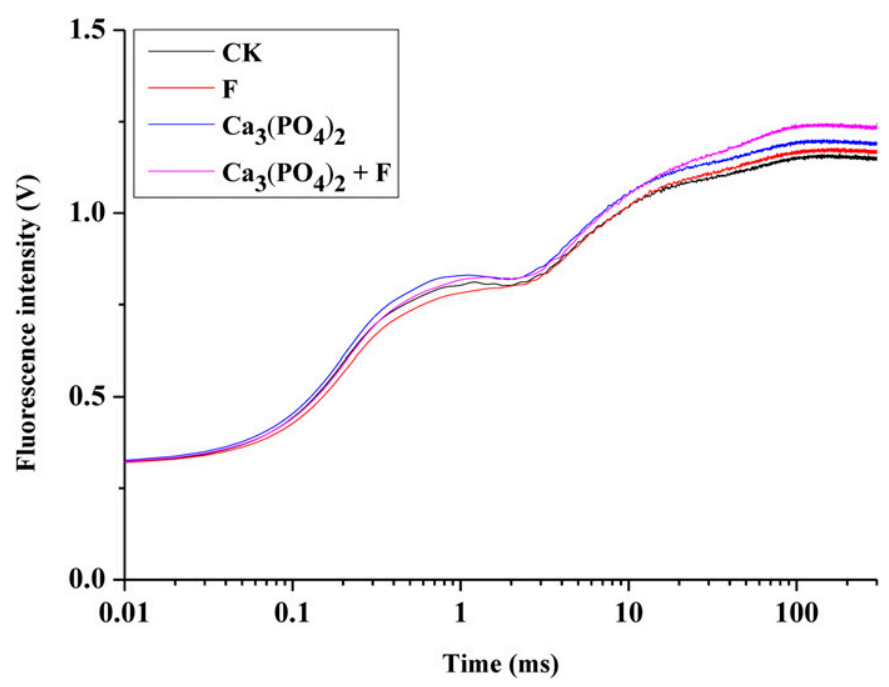

Fig. 5. Line plot showing the alterations of chlorophyll fluorescence transients (OJIP curve) in leaves of perennial ryegrass grown with or without Aspergillus aculeatus $(\mathrm{F})$ when $\mathrm{Ca}_{3}\left(\mathrm{PO}_{4}\right)_{2}$ concentration is 0 and $3 \mathrm{~g}$ per pot $\left(0.5 \mathrm{~kg}\right.$ growth substrate). $\mathrm{CK}$ represents control [i.e., no $\mathrm{Ca}_{3}\left(\mathrm{PO}_{4}\right)_{2}$ and $\mathrm{F}$ in medium]. plants were exposed to $\mathrm{Ca}_{3}\left(\mathrm{PO}_{4}\right)_{2}+$ $\mathrm{F}$ treatment, compared with other treatments.

The parameters of quantum yields and efficiencies, such as $\varphi \mathrm{E}_{0}$ and $\Psi \mathrm{E}_{0}$, were 1.13 - and 1.15higher in the $\mathrm{Ca}_{3}\left(\mathrm{PO}_{4}\right)_{2}+\mathrm{F}$ regimen than $\mathrm{Ca}_{3}\left(\mathrm{PO}_{4}\right)_{2}$ counterpart, respectively. Moreover, the specific energy fluxes, such as $\mathrm{ET}_{0} /$ reaction center (RC) and $\mathrm{RE}_{0} / \mathrm{RC}$, showed 1.10 -fold and 1.43-fold increase in the $\mathrm{Ca}_{3}\left(\mathrm{PO}_{4}\right)_{2}+\mathrm{F}$ group, compared with the $\mathrm{Ca}_{3}\left(\mathrm{PO}_{4}\right)_{2}$ group. In addition, performance index on absorption basis $\left(\mathrm{PI}_{\mathrm{ABS}}\right)$ and $\mathrm{PI}_{\text {total }}$ played an important role in displaying the PSII overall activity. In the $\mathrm{Ca}_{3}\left(\mathrm{PO}_{4}\right)_{2}+\mathrm{F}$ group, performance index $\mathrm{PI}_{\mathrm{ABS}}$ had a 1.28-, 1.27-, and 1.28 -fold increase respectively, compared with the $\mathrm{Ca}_{3}\left(\mathrm{PO}_{4}\right)_{2}$ group, $\mathrm{F}$ group, and $\mathrm{CK}$. The $\mathrm{PI}_{\text {total }}$ was 1.36-, 1.5-, and 1.5-fold higher, respectively, in the $\mathrm{Ca}_{3}\left(\mathrm{PO}_{4}\right)_{2}+\mathrm{F}$ group than the $\mathrm{Ca}_{3}\left(\mathrm{PO}_{4}\right)_{2}$ group, $\mathrm{F}$ group, and CK (Table 2).

\section{Metabolite homeostasis}

To investigate the alteration of metabolites as triggered by $\mathrm{A}$. aculeatus when the plants were subjected to P-deficiency stress, a GC-MS was applied. There were 26 metabolites, including eight amino acids, eight organic acids, six sugars, three fatty acids, and myo-inositol (Table 3).

As described in Fig. 6, the amino acids, such as valine, serine, and glutamic acid had a 1.36-, 1.16-, and 1.17-fold higher content in $\mathrm{Ca}_{3}\left(\mathrm{PO}_{4}\right)_{2}+\mathrm{F}$ group than $\mathrm{Ca}_{3}\left(\mathrm{PO}_{4}\right)_{2}$ group. By contrast, the organic acids, such as citric acids, fumaric acids, and succinic acids content were $0.78-, 0.82-$, and 0.94 -fold lower in $\mathrm{Ca}_{3}\left(\mathrm{PO}_{4}\right)_{2}+\mathrm{F}$ regime than $\mathrm{Ca}_{3}\left(\mathrm{PO}_{4}\right)_{2}$ only group.

\section{Discussion}

In this study, assessment of the A. aculeatus strain's characteristic of P-solubilizing showed that the fungus had the capacity to solubilize $\mathrm{P}$ when grown in the culture medium or/and growth substances. Earlier studies demonstrated that soil microorganisms were involved in a series of processes that participated in the transformation and cycling of P. In particular, microorganisms are capable of efficiently converting insoluble $\mathrm{P}$ into accessible forms, thus directly releasing $\mathrm{P}$ ions (i.e., phosphate $\mathrm{PO}_{4}{ }^{3-}$ ) into the solution (Rodríguez and Fraga, 1999; Zhu, 2002). These findings are in agreement with our study, in which inoculation of $A$. aculeatus improved the soluble $\mathrm{P}$ content of medium and soil. It is universally accepted that the mechanism of phosphate solubilization by microorganisms is attributed mainly to the secretion of organic acids 
Table 2. The photosynthetic parameters of perennial ryegrass leaves that were subjected to phosphorus deficiency stress after inoculation with Aspergillus aculeatus (F) using a pulse-amplitude modulation fluorometer.

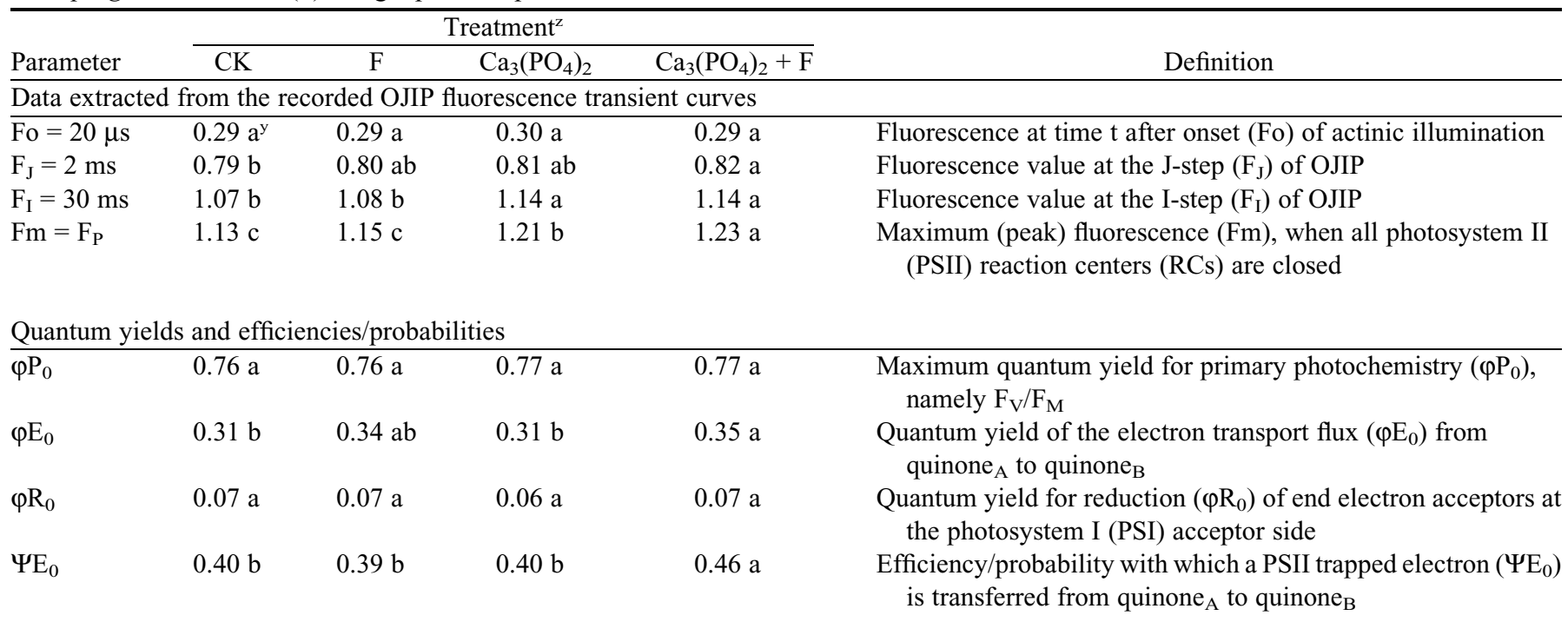

Specific energy fluxes (per active PSII reaction center)

\begin{tabular}{|c|c|c|c|c|c|}
\hline$\overline{\mathrm{ET}_{0} / \mathrm{RC}}$ & $1.35 \mathrm{ab}$ & $1.44 \mathrm{a}$ & $1.29 \mathrm{~b}$ & $1.42 \mathrm{ab}$ & Electron transport $\left(\mathrm{ET}_{0}\right)$ flux (further than Quinone ${ }_{\mathrm{A}}^{-}$) per RC \\
\hline $\mathrm{RE}_{0} / \mathrm{RC}$ & $0.19 \mathrm{~b}$ & $0.22 \mathrm{~b}$ & $0.21 \mathrm{~b}$ & $0.30 \mathrm{a}$ & $\begin{array}{l}\text { Electron flux reducing }\left(\mathrm{RE}_{0}\right) \text { end electron acceptors at the PSI } \\
\text { acceptor side, per } \mathrm{RC}\end{array}$ \\
\hline
\end{tabular}

Performance indexes [PI (combination of parameters)]

\begin{tabular}{|c|c|c|c|c|c|}
\hline$\overline{\mathrm{PI}_{\mathrm{ABS}}}$ & $0.46 \mathrm{~b}$ & $0.44 \mathrm{~b}$ & $0.46 \mathrm{~b}$ & $0.56 \mathrm{a}$ & Performance index on absorption basis $\left(\mathrm{PI}_{\mathrm{ABS}}\right)$ \\
\hline $\mathrm{PI}_{\text {total }}$ & $0.10 \mathrm{~b}$ & $0.10 \mathrm{~b}$ & $0.11 \mathrm{~b}$ & $0.15 \mathrm{a}$ & $\begin{array}{l}\text { Performance index for energy conservation from exciton to the } \\
\text { reduction of PSI end acceptors }\left(\mathrm{PI}_{\text {total }}\right)\end{array}$ \\
\hline
\end{tabular}

${ }^{\mathrm{z}}$ Treatments consisted of 0 and $3 \mathrm{~g} \mathrm{Ca}_{3}\left(\mathrm{PO}_{4}\right)_{2}$ added per pot. The chlorophyll $a$ fluorescence transient was determined using a pulse-amplitude modulation fluorometer on the fourth fully expanded leaves after a 30-min dark adaptation. The curves were evaluated with a red light of 3000 $\mu \mathrm{mol} \cdot \mathrm{m}^{-2} \cdot \mathrm{s}^{-1}$ to acquire the maximum fluorescence intensity. The chlorophyll $a$ fluorescence emission was induced by the strong light pulses and then was determined and digitized between $10 \mu \mathrm{s}$ and $320 \mathrm{~ms} ; \mathrm{CK}=$ control [i.e., no $\mathrm{Ca}_{3}\left(\mathrm{PO}_{4}\right)_{2}$ and $\mathrm{F}$ in soil].

${ }^{\mathrm{y}}$ Different letters indicate significant differences under four different treatments based on Student-Newman-Keuls test combining one-way analysis of variance $(P<0.05)$.

(Dobbelaere et al., 2003; Pratibha and Arvind, 2009; Taktek et al., 2015). In addition, it was previously reported that organic acid played a central role in the process of solubilizing $\mathrm{P}$ (Pratibha and Arvind, 2009) by using their carboxyl and hydroxyl groups to chelate the cations (mainly $\mathrm{Ca}^{2+}$ ), and thereby releasing $\mathrm{P}$ in soluble form (Kpomblekou and Tabatabai, 1994). In our results, an evident increase in the contents of tartaric acid, citric acid, malic acid, and aminoacetic acid were observed in A. aculeatus-inoculated liquid medium, compared with nonfungi treatment condition. Particularly, we observed that the production of organic acids was accompanied by a drop of the $\mathrm{pH}$ in the liquid medium, which further reaffirmed the phosphate solubilization of $A$. aculeatus. Collectively, these observations and our results suggested that $A$. aculeatus was capable of contributing toward the conversion of the insoluble $\mathrm{P}$ (such as tricalcium phosphate) into available P.

To elucidate whether the A. aculeatus could enhance the performance of plants subjected to P-impoverished soils, we focused on the growth index, such as growth rate and turf quality. Phosphorus is an essential macronutrient necessary for plant growth, whose low availability or deficiency is a primary constraint to crop yield around the world (Imen et al., 2015; Wang et al., 2010). Previous studies have reported that beneficial effects of $\mathrm{P}$ on cell division and root elongation improved plant growth and yield (Sharma et al., 2012). In our results, we found that application of the A. aculeatus could promote the growth of plants in the absence of $\mathrm{P}$ source compared with control, which is supported by the elevated growth rate and turf quality. Nevertheless, the promoting effect of fungus was enhanced remarkably on the growth rate and turf quality in the presence of tricalcium phosphate. This phenomenon might be attributed to the P-solubilizing capability of A. aculeatus, which enhanced the absorption and utilization of $P$ nutrition elements and thus facilitated the growth of plants. Our results accord with those of Imen et al. (2015), who suggested the decisive importance of inoculation of Rhizobia on improving plant growth and the P uptake. In addition, other previous reports also emphasized that P-solubilizing microorganisms, such as genera Bradyrhizobium and Aspergillus, could elevate the growth of radish (Raphanus sativus), maize (Zea mays), lettuce (Lactuca sativa), and wheat (Triticum turgidum) (Antoun et al., 1998; Chabot et al., 1996, 1998; Sharma et al., 2012). In the research of Chabot et al. (1996), it was demonstrated that phosphate solubilization effect of strains appears to be the most common mechanism of promoting plant growth. Overall, according to the observations and findings, we suggested that $A$. aculeatus as inoculant is involved in increasing plant $P$ acquisition and growth. 
Table 3. The parameters for analysis of amino, organic, and fatty acids, as well as sugars, and myo-inositol using gas chromatography-mass spectrometry of perennial ryegrass leaves that were subjected to phosphorus deficiency stress after inoculation with Aspergillus aculeatus (F).

\begin{tabular}{|c|c|c|c|c|}
\hline \multirow[b]{3}{*}{ Metabolite } & \multicolumn{4}{|c|}{ Treatment $^{2}$} \\
\hline & $\mathrm{CK}$ & $\mathrm{F}$ & $\mathrm{Ca}_{3}\left(\mathrm{PO}_{4}\right)_{2}$ & $\mathrm{Ca}_{3}\left(\mathrm{PO}_{4}\right)_{2}+\mathrm{F}$ \\
\hline & \multicolumn{4}{|c|}{$($ mean \pm SD $)$} \\
\hline \multicolumn{5}{|l|}{ Amino acids } \\
\hline Isoleucine & $0.0201 \pm 0.001 \mathrm{~b}$ & $0.0252 \pm 0.001 \mathrm{a}$ & $0.0193 \pm 0.001 b$ & $0.0240 \pm 0.003 \mathrm{a}$ \\
\hline Serine & $0.1660 \pm 0.003 b$ & $0.1731 \pm 0.007 \mathrm{~b}$ & $0.1765 \pm 0.010 \mathrm{~b}$ & $0.2052 \pm 0.016 \mathrm{a}$ \\
\hline Threonine & $0.0926 \pm 0.001 \mathrm{~b}$ & $0.1046 \pm 0.007 \mathrm{a}$ & $0.0816 \pm 0.001 \mathrm{~b}$ & $0.1112 \pm 0.010 \mathrm{a}$ \\
\hline Trihydroxybutyric acid & $0.0190 \pm 0.001 \mathrm{a}$ & $0.0194 \pm 0.002 \mathrm{a}$ & $0.0075 \pm 0.001 \mathrm{~b}$ & $0.0091 \pm 0.002 \mathrm{~b}$ \\
\hline Glutamic acid & $0.0738 \pm 0.003 \mathrm{a}$ & $0.0694 \pm 0.005 \mathrm{a}$ & $0.0482 \pm 0.017 b$ & $0.0563 \pm 0.008 \mathrm{~b}$ \\
\hline Tyrosine & $0.0061 \pm 0.001 \mathrm{a}$ & $0.0075 \pm 0.001 \mathrm{a}$ & $0.0064 \pm 0.001 \mathrm{a}$ & $0.0094 \pm 0.002 \mathrm{a}$ \\
\hline \multicolumn{5}{|l|}{ Organic acids } \\
\hline Succinic acid & $0.0249 \pm 0.003 \mathrm{a}$ & $0.0186 \pm 0.003 \mathrm{~b}$ & $0.0188 \pm 0.002 b$ & $0.0178 \pm 0.002 b$ \\
\hline Fumaric acid & $0.0212 \pm 0.001 \mathrm{~b}$ & $0.0282 \pm 0.000 \mathrm{a}$ & $0.0159 \pm 0.001 \mathrm{c}$ & $0.0130 \pm 0.002 \mathrm{~d}$ \\
\hline Glyceric acid & $0.0374 \pm 0.017 \mathrm{a}$ & $0.0358 \pm 0.005 \mathrm{a}$ & $0.0442 \pm 0.002 \mathrm{a}$ & $0.0405 \pm 0.000 \mathrm{a}$ \\
\hline Gluconic acid & $0.0101 \pm 0.001 \mathrm{a}$ & $0.0092 \pm 0.000 \mathrm{a}$ & $0.0133 \pm 0.003 \mathrm{a}$ & UD \\
\hline \multicolumn{5}{|l|}{ Sugars } \\
\hline Sucrose & $2.8234 \pm 0.278 \mathrm{a}$ & $3.0753 \pm 0.447 \mathrm{a}$ & $3.1705 \pm 0.884 \mathrm{a}$ & $2.0877 \pm 0.113 \mathrm{a}$ \\
\hline Galactose & $0.0875 \pm 0.005 \mathrm{ab}$ & $0.0921 \pm 0.011 \mathrm{a}$ & $0.0672 \pm 0.008 b$ & $0.0729 \pm 0.011 \mathrm{ab}$ \\
\hline Fructose & $0.4159 \pm 0.004 \mathrm{a}$ & $0.4329 \pm 0.135 \mathrm{a}$ & $0.3112 \pm 0.031 \mathrm{a}$ & $0.1137 \pm 0.014 \mathrm{~b}$ \\
\hline Psicose & $0.2552 \pm 0.003 \mathrm{a}$ & $0.1952 \pm 0.108 \mathrm{a}$ & $0.1798 \pm 0.011 \mathrm{a}$ & UD \\
\hline Mannose & $0.0879 \pm 0.042 \mathrm{c}$ & $0.7354 \pm 0.046 \mathrm{bc}$ & $0.1715 \pm 0.047 \mathrm{~b}$ & $0.2366 \pm 0.064 \mathrm{a}$ \\
\hline Allose & $0.2754 \pm 0.095 \mathrm{a}$ & $0.0446 \pm 0.007 \mathrm{~b}$ & $0.0652 \pm 0.025 \mathrm{~b}$ & $0.0416 \pm 0.007 \mathrm{~b}$ \\
\hline \multicolumn{5}{|l|}{ Fatty acids } \\
\hline Hexadecanoic acid & $0.1757 \pm 0.032 \mathrm{a}$ & $0.1007 \pm 0.013 \mathrm{a}$ & $0.1570 \pm 0.049 \mathrm{a}$ & $0.0934 \pm 0.043 \mathrm{a}$ \\
\hline
\end{tabular}

${ }^{\mathrm{z}}$ Treatments consisted of 0 and $3 \mathrm{~g} \mathrm{Ca}_{3}\left(\mathrm{PO}_{4}\right)_{2}$ added to per pot. The fully expanded perennial ryegrass leaves $(\approx 0.3 \mathrm{~g})$ were extracted and determined by gas chromatography-mass spectrometry using the retention time coupled with available compound libraries. Relative quantification of the metabolite was calculated according to the internal standard (ribitol); $\mathrm{CK}=\operatorname{control}\left[\mathrm{i} . \mathrm{e}\right.$., no $\mathrm{Ca}_{3}\left(\mathrm{PO}_{4}\right)_{2}$ and $\mathrm{F}$ in soil].

${ }^{\mathrm{y}}$ Different letters indicate significant differences under four different treatments based on Student-Newman-Keuls test combining one-way analysis of variance $(P<0.05)$.

$\mathrm{UD}=$ undeterminable

Plants that are exposed to P-impoverished soils would elicit the alteration in photosynthesis that is extremely sensitive to any environment changes (Lima et al., 2000; Sun et al., 2009). Several studies also highlighted the effects of $\mathrm{P}$ on photosynthesis, whereby there was a remarkable decline in the photosynthesis induced by insufficient P-supply (Foyer and Spencer, 1986; Terry, 1989). Chlorophyll $a$ fluorescence is a useful tool that could probe the impact of abiotic stress on photosynthesis (Kalaji et al., 2011). Consistent with those findings, our results showed that chlorophyll $a$ fluorescence transient (OJIP curve) of plant leaves significantly reduced in the control [i.e., no $\mathrm{Ca}_{3}\left(\mathrm{PO}_{4}\right)_{2}$ and $A$. aculeatus in medium], compared with $\mathrm{Ca}_{3}\left(\mathrm{PO}_{4}\right)_{2}$ treatment or $\mathrm{Ca}_{3}\left(\mathrm{PO}_{4}\right)_{2}+$ A. aculeatus treatment. This result might be attributed to the inadequate supply of $\mathrm{P}$, which caused a decrease in leaf area, altered leaf chlorophyll, and protein content (Li et al., 2006; Plesničar et al., 1994; Usuda, 1995;). It is noteworthy that the OJIP had an obvious increase in $\mathrm{Ca}_{3}\left(\mathrm{PO}_{4}\right)_{2}+$ A. aculeatus group, compared with $\mathrm{Ca}_{3}\left(\mathrm{PO}_{4}\right)_{2}$ treatment, which suggests the important role of A. aculeatus in dissolving $\mathrm{P}$ and hence contributing positively toward photosynthesis. Furthermore, parallel to enhanced OJIP, photosynthetic parameters, such as $\varphi \mathrm{E}_{0}, \Psi \mathrm{E}_{0}, \mathrm{RE}_{0} / \mathrm{RC}, \mathrm{PI}_{\mathrm{ABS}}$, and $\mathrm{PI}_{\text {total }}$, showed an evident increase in $\mathrm{Ca}_{3}\left(\mathrm{PO}_{4}\right)_{2}+$ A. aculeatus group, compared with the $A$. aculeatus group or $\mathrm{Ca}_{3}\left(\mathrm{PO}_{4}\right)_{2}$ group. This result indicated that increased availability of the $\mathrm{P}$ content induced by $A$. aculeatus was closely associated with enhanced photosynthetic efficiency accompanied by the elevated photosynthetic parameters and OJIP curve. Consistent with those observations, a study by Yu et al. (2010) found that the net photosynthetic rate of leaves was enhanced significantly by phosphate-solubilizing bacteria (Stevenson, 1994; Yu et al., 2010). Therefore, those results implied that $A$. aculeatus through its phosphate solubilization regulated photosynthesis of plant under $\mathrm{P}$-impoverished soils.

A number of studies have illustrated that metabolites are considered as an important tool in exploring plant stress 

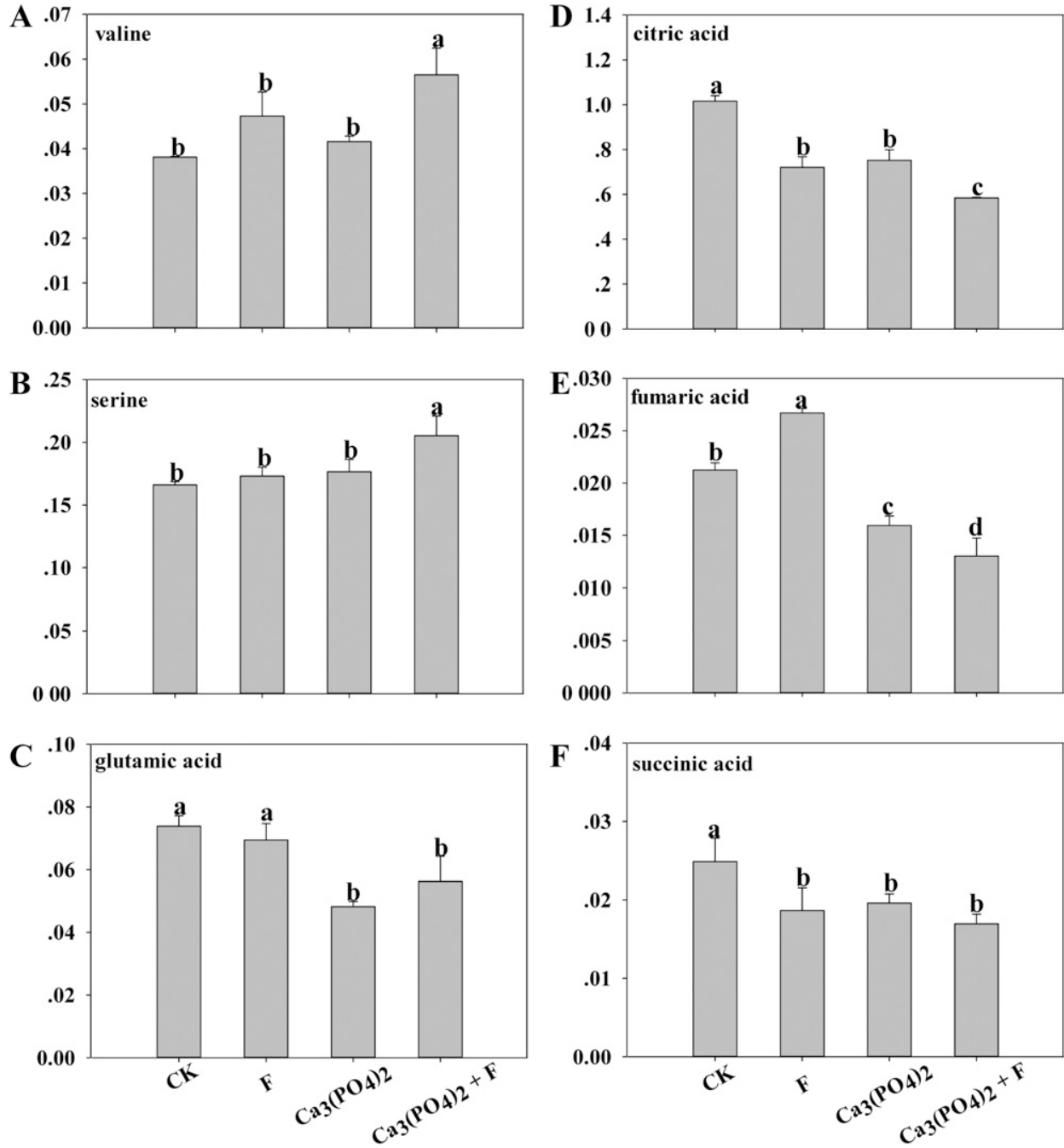

Fig. 6. Bar plots showing the influences of the Aspergillus aculeatus $(\mathrm{F})$ on specific amino acids [valine (A), serine (B), and glutamic $(\mathbf{C})$ acid] and organic acids [citric $(\mathbf{D})$, fumaric $(\mathbf{E})$, and succinic $(\mathbf{F})$ acid] of perennial ryegrass leaves. $\mathrm{CK}$ represents control [i.e., no $\mathrm{Ca}_{3}\left(\mathrm{PO}_{4}\right)_{2}$ and $\mathrm{F}$ in medium]. $\mathrm{Ca}_{3}\left(\mathrm{PO}_{4}\right)_{2}$ concentration is 0 and $3 \mathrm{~g}$ per pot $(0.5 \mathrm{~kg}$ growth substrate). The numbers marked with the same small letter indicate insignificant differences under four different treatments $(P<0.05)$.

responses, including shortage in nutrients, ion stresses, oxidative stress, and so on (Guy et al., 2008; Obata and Fernie, 2012; Shulaev et al., 2008). A previous study showed that environmental changes could disrupt and alter the metabolites of plants (Widodo et al., 2009). It was confirmed that leaf amino acid content was significantly reduced or enhanced (Julia et al., 2015; Lima et al., 2000), organic acid content increased (Julia et al., 2015), and sugar content also increased (Ganie et al., 2015; Hernández and Vance, 2007) under Pdeficiency condition. Consistent with those reports, our results indicated that leaf amino acid content increased or decreased dramatically and organic acid content increased distinctly when the plants were subjected to P-deficiency stress. Most of the detected amino acids were remarkably decreased in Pdeficient levels, which are mainly due to the inadequacy of energy required for the synthesis of amino acids in P-deficiency plants, thereby contributing to the drop of amino acid content (Lima et al., 2000). Conversely, an accumulation of only a few of the amino acids might be because of accelerated protein degradation and suppressed protein synthesis under P-limiting conditions (Ganie et al., 2015). Moreover, it was evidenced that organic acids acted as crucial roles in the plant adaptation to nutrient deficiency (Wang and Shen, 2006), which explains the enhancement of organic acids in plant leaves exposed to P-deficiency condition. In addition, another study confirmed that those organic acids were preferred $\mathrm{P}$ reserves for P-deficiency tolerance ( $\mathrm{Li}$ et al., 2007). Interestingly, in the $\mathrm{Ca}_{3}\left(\mathrm{PO}_{4}\right)_{2}+\mathrm{F}$ group, amino acid and organic acid content exhibited a converse trend when compared with other treatments (i.e., P-deficiency condition), which might be the result of phosphate solubilization of $\mathrm{A}$. aculeatus that enhanced the acquisition and utilization efficiency of $\mathrm{P}$ under P-deficiency stress. Therefore, the metabolite profiles of shoots were used to gather insight of the metabolic adjustments to plants faced with the P-deficient environment, and $A$. aculeatus may be involved in modulating metabolite accumulation.

In conclusion, our results demonstrated that $A$. aculeatus has the capacity to solubilize insoluble $\mathrm{P}$ into soluble $\mathrm{P}$ and accelerate plant growth under low P stress. According to our findings, we put forward the mechanism of $A$. aculeatus to solubilize insoluble $\mathrm{P}$ in a liquid medium mainly due to organic acids secreted by fungi. Furthermore, A. aculeatus promotes the growth of perennial ryegrass subjected to P-impoverished soils and the main performance is in the following three aspects: 1) A. aculeatus could promote plant growth rate and turf quality; 2) A. aculeatus can enhance plant photosynthetic efficiency; and 3) A. aculeatus could regulate synthesis and accumulation of metabolites (amino acids, organic acids, and sugars). We highlight the high potential of this fungus in solubilizing insoluble $\mathrm{P}$ and appraise the potential of the fungus to be used in commercial biofertilizers.

\section{Literature Cited}

Altpeter, F. Perennial ryegrass (Lolium perenne L.). 2006. Methods Mol. Biol. 344:55-64.

Antoun, H., C.J. Beauchamp, N. Goussard, R. Chabot, and R. Lalande. 1998. Potential of Rhizobium and Bradyrhizobium species as plant growth promoting rhizobacteria on non-legumes: Effect on radishes (Raphanus sativus L.). Plant Soil 204:57-67.

Calvo, P., L. Nelson, and J.W. Kloepper. 2014. Agricultural uses of plant biostimulants. Plant Soil 383:3-41. 
Chabot, R., H. Antoun, and M.P. Cescas. 1996. Growth promotion of maize and lettuce by phosphate-solubilizing Rhizobium leguminosarum biovar. phaseoli. Plant Soil 184:311-321.

Chabot, R., C.J. Beauchamp, J.W. Kloepper, and H. Antoun. 1998. Effect of phosphorus on root colonization and growth promotion of maize by bioluminescent mutants of phosphate-solubilizing Rhizobium leguminosarum biovar phaseoli. Soil Biol. Biochem. 30:1615-1618.

Chacon, N., W.L. Silver, E.A. Dubinsky, and D.F. Cusack. 2006. Iron reduction and soil phosphorus solubilization in humid tropical forests soils: The roles of labile carbon pools and an electron shuttle compound. Biogeochemistry 78:67-84.

Chen, K., L. Chen, J. Fan, and J. Fu. 2013. Alleviation of heat damage to photosystem II by nitric oxide in tall fescue. Photosynth. Res. 116:21-31.

Dobbelaere, S., J. Vanderleyden, and Y. Okon. 2003. Plant growthpromoting effects of diazotrophs in the rhizosphere. Crit. Rev. Plant Sci. 22:107-149.

Foyer, C. and C. Spencer. 1986. The relationship between phosphate status and photosynthesis in leaves. Planta 167:369-375.

Ganie, A.H., A. Ahmad, R. Pandey, I.M. Aref, P.Y. Yousuf, S. Ahmad, and M. Iqbal. 2015. Metabolite profiling of low-P tolerant and low-P sensitive maize genotypes under phosphorus starvation and restoration conditions. PLoS One 10:e0129520.

Guy, C., J. Kopka, and T. Moritz. 2008. Plant metabolomics coming of age. Physiol. Plant. 132:113-116.

Hernández, G. and C.P. Vance. 2007. Phosphorus stress in common bean: Root transcript and metabolic responses. Plant Physiol. 144:752-767.

Imen, H., A. Neila, B. Adnane, B. Manel, Y. Mabrouk, M. Saidi, and S. Bouaziz. 2015. Inoculation with phosphate solubilizing mesorhizobium strains improves the performance of chickpea (Cicer aritenium L.) under phosphorus deficiency. J. Plant Nutr. 38:1656-1671.

Julia, M., G. Victoria, N. Karsten, and Z. Christian. 2015. Metabolic adaptations of white lupin roots and shoots under phosphorus deficiency. Front. Plant Sci. 6:e0129520.

Kalaji, H.M., Govindjee, K. Bosa, J. Kościelniak, and K. Żuk-Gołaszewska. 2011. Effects of salt stress on photosystem II efficiency and $\mathrm{CO}_{2}$ assimilation in two Syrian barley landraces. Environ. Expt. Bot. 73: 64-72.

Khan, M.S., A. Zaidi, and P.A. Wani. 2007. Role of phosphate solubilizing microorganisms in sustainable agriculture. Rev. Agron. Sustainable Dev. 27:29-43.

Kpomblekou, A.K. and M.A. Tabatabai. 1994. Effect of organic acids on the release of phosphorus from phosphate rocks1. Soil Sci. 158:442-453.

Li, K., C. Xu, K. Zhang, A. Yang, and J. Zhang. 2007. Proteomic analysis of roots growth and metabolic changes under phosphorus deficit in maize (Zea mays L.) plants. Proteomics 7:1501-1512.

Li, X., S. Han, G. Wang, X. Liu, E. Amombo, Y. Xie, and J. Fu. 2017. The fungus Aspergillus aculeatus enhances salt-stress tolerance, metabolite accumulation, and improves forage quality in perennial ryegrass. Front. Microbiol. 8:1664.

Li, Y., A. Luo, M.J. Hassan, and X. Wei. 2006. Effect of phosphorus deficiency on leaf photosynthesis and carbohydrates partitioning in two rice genotypes with contrasting low phosphorus susceptibility. Rice Sci. 13:283-290.

Lima, J.D., F.B.D. Matta, and P. Mosquim. 2000. Growth attributes, xylem sap composition, and photosynthesis in common bean as affected by nitrogen and phosphorus deficiency. J. Plant Nutr. 23:937-947.

Liu, F., H. Liu, H. Zhou, Z. Dong, X. Bai, P. Bai, and J. Qiao. 2014. Isolation and characterization of phosphate-solubilizing bacteria from betel nut (Areca catechu) and their effects on plant growth and phosphorus mobilization in tropical soils. Biol. Fertil. Soils 50:927-937.
Murphy, J. and J.P. Riley. 1962. A modified single solution method for the determination of phosphate in natural waters. Anal. Chim. Acta 27:31-36.

Narsian, V. and H.H. Patel. 2000. Aspergillus aculeatus as a rock phosphate solubilizer. Soil Biol. Biochem. 32:559-565.

Obata, T. and A.R. Fernie. 2012. The use of metabolomics to dissect plant responses to abiotic stresses. Cell. Mol. Life Sci. 69:3225-3243.

Plesničar, M., R. Kastori, N. Petrović, and D. Panković. 1994. Photosynthesis and chlorophyll fluorescence in sunflower (Helianthus annuus L.) leaves as affected by phosphorus nutrition. J. Expt. Bot. 45:919-924.

Pratibha, V. and G. Arvind. 2009. Organic acid production in vitro and plant growth promotion in maize under controlled environment by phosphate-solubilizing fluorescent Pseudomonas. BMC Microbiol. 9:174.

Richardson, A.E. 2001. Prospects for using soil microorganisms to improve the acquisition of phosphorus by plants. Austral. J. Plant Physiol. 28:897-906.

Richardson, A.E., J. Barea, A.M. Mcneill, and C. Prigentcombaret. 2009. Acquisition of phosphorus and nitrogen in the rhizosphere and plant growth promotion by microorganisms. Plant Soil 321:305-339.

Rodríguez, H. and R. Fraga. 1999. Phosphate solubilizing bacteria and their role in plant growth promotion. Biotechnol. Adv. 17:319-339.

Sharma, A., U.S. Rawat, and B.K. Yadav. 2012. Influence of phosphorus levels and phosphorus solubilizing fungi on yield and nutrient uptake by wheat under sub-humid region of Rajasthan, India. ISRN Agron. 2012:1-9.

Shui, G. and L. Leong. 2002. Separation and determination of organic acids and phenolic compounds in fruit juices and drinks by highperformance liquid chromatography. J. Chromatography 977:89-96.

Shulaev, V., D. Cortes, G. Miller, and R. Mittler. 2008. Metabolomics for plant stress response. Physiol. Plant. 132:199-208.

Smith, S.E. and D.J. Read. 1997. Mycorrhizal symbiosis. 2nd ed. Academic Press, Pittsburgh, PA.

Stevenson, F.J. 1994. Humus chemistry: Genesis, composition, reactions. 2nd ed. Wiley, New York, NY.

Sun, C., H. Qi, J. Hao, L. Miao, J. Wang, Y. Wang, M. Liu, and L. Chen. 2009. Single leaves photosynthetic characteristics of two insect-resistant transgenic cotton (Gossypium hirsutum L.) varieties in response to light. Photosynthetica 47:399-408.

Taktek, S., M. Trépanier, P.M. Servin, M. St-Arnaud, Y. Piché, J.A. Fortin, and H. Antoun. 2015. Trapping of phosphate solubilizing bacteria on hyphae of the arbuscular mycorrhizal fungus Rhizophagus irregularis DAOM 197198. Soil Biol. Biochem. 90:1-9.

Terry, N. 1989. Leaf phosphate status, photosynthesis, and carbon partitioning in sugar beet. I. changes in growth, gas exchange, and calvin cycle enzymes. Plant Physiol. 90:814-819.

Turgeon, A.J. 1991. Turfgrass management. Prentice Hall, Englewood Cliffs, NJ.

Usuda, H. 1995. Phosphate deficiency in maize. V. Mobilization of nitrogen and phosphorus within shoots of young plants and its relationship to senescence. Plant Cell Physiol. 36:1041-1049.

Velázquez, E., P. García-Fraile, A. Skorupska, J. Wielbo, D. Kidaj, A. Peix, L.R. Silva, J. Musarrat, and A. Zaidi. 2010. Microbes for legume improvement. Springer, Vienna, Austria.

Wang, J. and Q. Shen. 2006. Roles of organic acid metabolism in plant adaptation to nutrient deficiency and aluminum toxicity stress. Chinese J. Appl. Ecol. 17:2210-2216.

Wang, X., J. Shen, and H. Liao. 2010. Acquisition or utilization, which is more critical for enhancing phosphorus efficiency in modern crops? Plant Sci. 179:302-306.

Weber, E., E. George, D.P. Beck, M.C. Saxena, and H. Marschner. 1992. Vesicular-arbuscular mycorrhiza and phosphorus uptake of chickpea grown in northern Syria. Expt. Agr. 28:433-442.

Whitelaw, M.A. 2000. Growth promotion of plants inoculated with phosphate-solubilizing fungi. Adv. Agron. 69:99-151.

Widodo, J.H. Patterson, E. Newbigin, M. Tester, A. Bacic, and U. Roessner. 2009. Metabolic responses to salt stress of barley (Hor- 
deum vulgare L.) cultivars, 'Sahara' and 'Clipper', which differ in salinity tolerance. J. Expt. Bot. 60:4089-4103.

Wilkins, P.W. 1991. Breeding perennial ryegrass for agriculture. Euphytica 52:201-214.

Xie, Y., H. Luo, Z. Du, L. Hu, and J. Fu. 2014a. Identification of cadmium-resistant fungi related to $\mathrm{Cd}$ transportation in bermudagrass [Cynodon dactylon (L.) Pers.]. Chemosphere 117:786-792.

Xie, Y., L. Hu, Z. Du, X. Sun, E. Amombo, J. Fan, and J. Fu. 2014 b. Effects of cadmium exposure on growth and metabolic profile of bermudagrass [Cynodon dactylon (L.) Pers.]. PLoS One 9:e115279.

Xie, Y., S. Han, X. Li, E. Amombo, and J. Fu. 2017. Ameliorates of salt stress on bermudagrass by the fungus Aspergillus aculeatus. Mol. Plant Microbe Interact. 30:245-254.
Xie, Y., X. Li, X. Liu, E. Amombo, L. Chen, and J. Fu. 2018. Application of Aspergillus aculeatus to rice roots reduces $\mathrm{Cd}$ concentration in grain. Plant Soil 422:409-422.

Xiong, Y., S. Fei, R. Arora, E.C. Brummer, R.E. Barker, G. Jung, and S.E. Warnke. 2007. Identification of quantitative trait loci controlling winter hardiness in an annual $\times$ perennial ryegrass interspecific hybrid population. Mol. Breed. 19:125-136.

Yu, X., T. Zhu, X. Liu, and G. Liu. 2010. Effects of different phosphate solubilizing bacteria on growth, photosynthetic characteristics and phosphate nutrition of pecan. J. Fruit Sci. 27:725-729.

Zhu, J. 2002. Screening and identification of microorganisms capable of utilizing phosphate adsorbed by goethite. Commun. Soil Sci. Plant Anal. 33:647-663. 